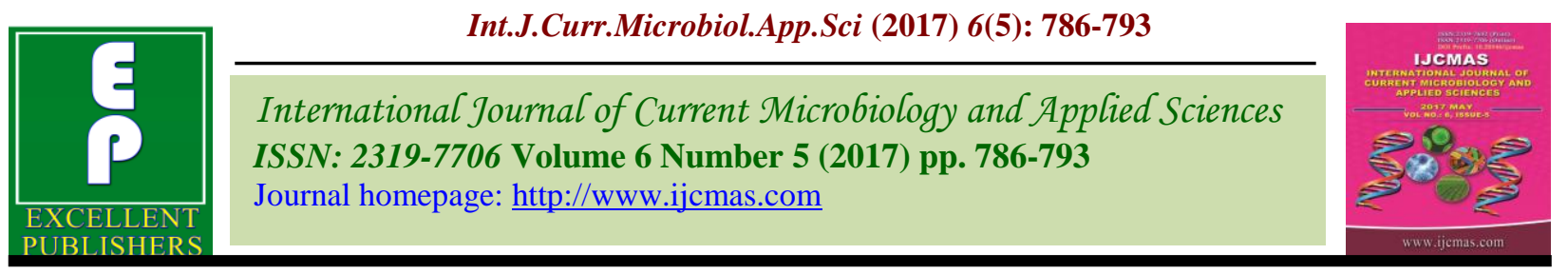

Original Research Article

https://doi.org/10.20546/ijcmas.2017.605.089

\title{
Performance of a Set of Tomato Parental Lines and their Hybrids for Quality and Yield under Conditions of Bengaluru, India
}

\author{
M.V. Bharathkumar ${ }^{1 *}$, A.T. Sadashiva ${ }^{2}$ and Pradeep Kumar Jatav ${ }^{3}$ \\ ${ }^{1}$ CCS Haryana Agricultural University, Hisar-125 004, India \\ ${ }^{2}$ Principal Scientist, Indian Institute of Horticultural Research, Bengaluru-560 089, India \\ ${ }^{3}$ Indian Institute of Agricultural Research, New Delhi, India \\ *Corresponding author
}

\begin{abstract}
A B S T R A C T

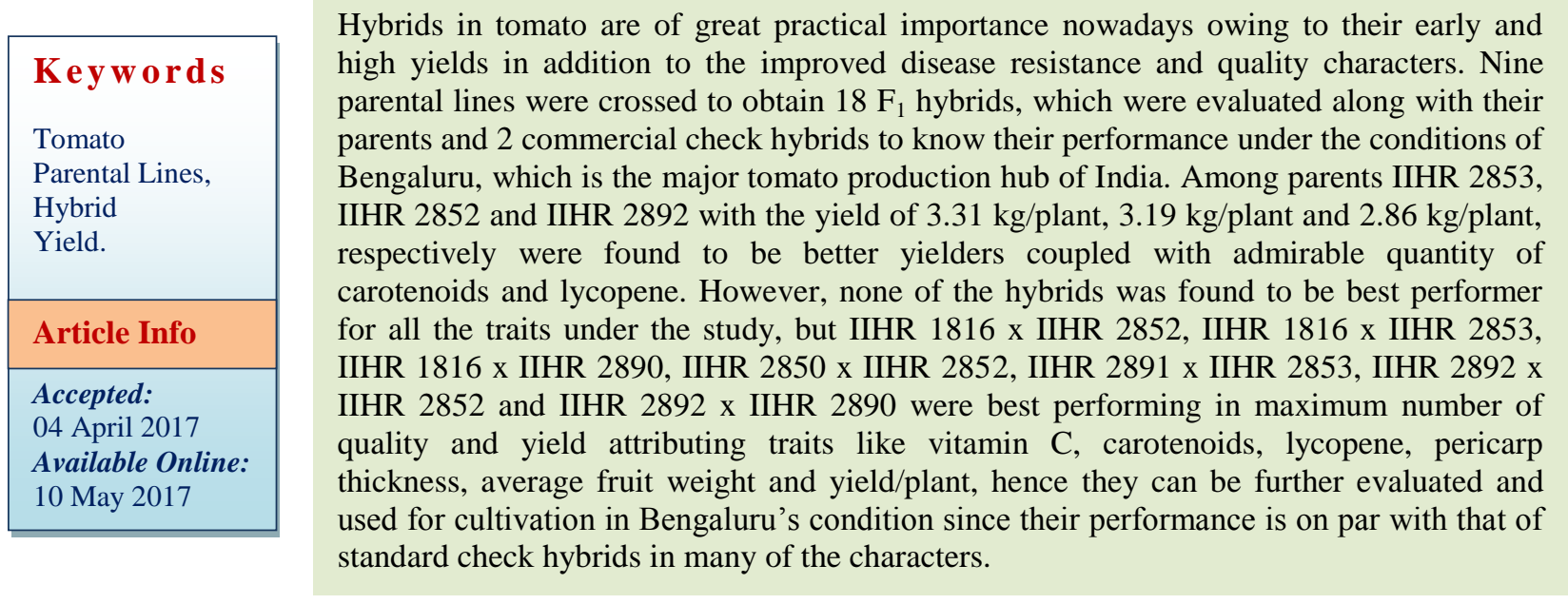

\section{Introduction}

Tomato, being the most widely used and nutritive vegetable has a special importance in Indian subcontinent due to its inevitable use in almost all the dishes, processed products like pickle, jam, ketchup and also as a delicious salad vegetable. Tomato (Solanum lycopersicum L.) belongs to the family solanaceae with chromosome number $2 n=24$ and is a native of Peru, Ecuador region (Rick, 1969) and alleged to have been carried to India during the $16^{\text {th }}$ century through far eastern countries. Although, tomato does not rank high in nutritional value, by virtue of volume consumed, it contributes significantly to the dietary intake of vitamins $\mathrm{A}$ and $\mathrm{C}$, as well as essential minerals and other nutrients. Fresh and processed tomatoes are the lushest sources of the dietary antioxidant lycopene, which possibly protects cells from oxidants that have been associated with cancer (Rao and Rao, 2007). It is also a source of other compounds with antioxidant activities, including chlorogenic acid, plastoquinones, rutin, tocopherol and xanthophylls (Leonardi et al., 2000). It is a warm season crop reasonably resistant to heat and drought and 
grows under wide range of soil and climatic conditions.

Since tomato is a very good source of income to small and marginal farmers in India, it ranks third in area immediately after potato and onion crop and second in production immediately after the potato Crop (Anon., 2016). Even though India is the second largest tomato producer in the world next to China, the productivity lies large below the average productivity of many small countries due to number of reasons ranging from climatic conditions to technology employed in management of crop, but most importantly the poor selection of varieties suitable to a particular region. Seed source or the variety is the cheapest input in crop production, yet the most important and yield deciding factor in the course. Commercially grown varieties are low yielder as compared to hybrid tomatoes which have advantages of uniformity in shape and size, increased vigor, early maturity, high yield and resistance to specific pests and pathogens. Hence the present experiment was designed to evaluate the 18 tomato hybrids developed by 9 diverse parents for quality and yield components under the conditions of Bengaluru (Karnataka).

\section{Materials and Methods}

Present investigation was carried out at Experimental plot of Division of vegetable crops, Indian Institute of Horticultural Research (IIHR), Bengaluru, Karnataka. The experimental field was located at an altitude of 890 meters above MSL 130.58' N latitude and 770.37 ' E longitude.

\section{Hybrid seed production}

Nine diverse genotypes, namely IIHR 977, IIHR 1816, IIHR 2848, IIHR 2850, IIHR 2891, IIHR 2892 as female parents (Lines) and IIHR 2852, IIHR 2853, IIHR 2890 as male parents (Testers) were crossed in Line $\times$ Tester fashion during rabi 2013-14 to obtain 18 hybrids. Healthy flower buds in a cyme preferably of the first flush which were expected to open in the next day were selected for emasculation and pollination. The selected buds were emasculated by hand using forceps in the evening hours between $4.00 \mathrm{pm}$ to $6.00 \mathrm{pm}$ and were covered with butter paper bags to avoid contamination. The pollination of emasculated flowers was done next day morning during anthesis time (7.00 am to $10.30 \mathrm{am})$. Well opened flowers with dehisced anthers were collected from the male parents, the butter paper bag was removed carefully and stigma was brought in contact with dehisced anthers of male flowers. The female flower was covered with white coloured butter paper bag immediately after crossing for easy identification and to avoid the contamination from other pollen. The pedicel of each pollinated flowers was tied with label bearing information of female and male parents and date of crossing for identification. The ripe fruits were harvested and the seeds were extracted by fermentation method. Simultaneously, some flowers in each of these genotypes were selfed by covering the flowers with butter paper bags.

\section{Nursery Raising and Cultivation}

The seeds of 18 hybrids along with their parents and standard checks (ArkaRakshak and Abhinava) were sown during first week of January 2014 in the plug trays of 98 cells and named accordingly. They were managed well by watering under the protected structure and seedlings reached optimum stage for transplanting in four weeks after sowing. The experimental plot was ploughed repeatedly and brought to a fine filth and FYM was applied at the rate of $25 \mathrm{t}$ per ha at the time of land preparation before transplanting of seedlings and ridges were made, polythene mulch was used to avert weeds and to 
preserve the root zone moisture. The crop was facilitated with inline dripper through which the irrigation and recommended nutrition was provided for tomato plants as per package of practices recommended by IIHR for tomato crop. The entire plot was divided into subplots all 29 entries (9 parents, 18 hybrids and 2 commercial checks) were assigned to different sub-plots in all replications using random table. Seedlings were transplanted in randomized block design with three replications during February 2014. Each entry was represented by 40 plants in each replication at spacing of $100 \mathrm{~cm}$ between rows and $45 \mathrm{~cm}$ within row. Seedlings transplanted and were trained using jute twines on to a metal wire that is supported by the wooden stakes fixed at every $5 \mathrm{~m}$ along the row. Each branch of the plant are tied on to the metal wire as and when they start flowering using separate twines, this supports the fruits to stay high and to avoid touching to the ground. Additionally, spray of vegetable special, a micronutrient mixture developed at IIHR was sprayed on plants at flowering and thereafter at every harvest that helps in better plant growth, flowering and yield. Observations on five randomly selected plants were recorded for various growth, yield and quality attributing traits to understand the performance of tomato hybrids and check varieties.

\section{Results and Discussion}

The mean performance of the parents and hybrids for various characters under investigation are presented in Table 1 and Table 2, respectively and the results are presented under various sub-headings as follows.

Morphological traits: A range of variation for plant height was observed among the parents and hybrids with IIHR 1816 being the shortest $(63.42 \mathrm{~cm})$ to IIHR $2853(89.54 \mathrm{~cm})$ being the tallest. Among the $\mathrm{F}_{1}$ 's, the lowest plant height of $73.67 \mathrm{~cm}$ was recorded in IIHR $1816 \times$ IIHR 2890 and the highest $(91.08 \mathrm{~cm})$ in IIHR $2848 \times$ IIHR 2853. IIHR 2853 (5.33) had least number of branches whereas IIHR 2890 (6.87) had highest number of branches followed by IIHR 2848 (6.61). Amongst the hybrids, IIHR $977 \mathrm{x}$ IIHR 2890 (7.2) was observed to have most branches, whereas IIHR 2850 x IIHR 2890 (5.00) had minimum number of branches per plant. Number of branches decides the production of leaves that decides the efficiency of photosynthesis and number of flowers per plant which may contribute towards better yield, the results were in approval with the work of Arun et al., (2004).

\section{Earliness}

The hybrid that flowers or fruits earlier is known to add additional income by exploiting the market demand in the early days of the season, and hence the need is for hybrid with early bearing. Among the parents, IIHR 2892 was found to be earliest to flower (28 days after transplanting) followed by IIHR 1816 , IIHR 2852 and IIHR 2848 (28.33 DAT). IIHR 2891 x IIHR 2852 was earliest to flower (26.33 DAT) among the hybrids, while IIHR 1816 x IIHR 2852, IIHR 1816 x IIHR 2853 and IIHR $2891 \times$ IIHR 2853 took 27.33 days after transplanting for 50 per cent flowering, which are comparatively earlier than checks Arka Rakshak (31 DAT) and Abhinava (29 DAT). Lekshmi and Celine (2015) also revealed that the flowering of tomato hybrids was ranged between 26.27 days 29 days after transplanting under polyhouse conditions of Vellayani, Kerala. IIHR 977 and IIHR 2890 (56.33 days) were early to attain fruit maturity among parents, while IIHR 2848 (64.33 days) was late. Arka Rakshak (62.33 DAT) and Abhinava (60 DAT) were bit late to attain fruit maturity. Among the hybrids, IIHR 977 x IIHR 2890 (56.33 days) took minimum days 
to attain first fruit maturity, whereas IIHR 2848 x IIHR 2853 and IIHR 2848 x IIHR 2890 (62.33 days) took more number of days.

\section{Quality traits}

Firmness of fruit is most important trait since it influences the shipping ability and keeping quality of fruit. Parent IIHR 2853 had firm fruits $\left(8.37 \mathrm{~kg} / \mathrm{cm}^{2}\right)$, followed by IIHR 2850 $\left(8.14 \mathrm{~kg} / \mathrm{cm}^{2}\right)$, IIHR $2852\left(7.42 \mathrm{~kg} / \mathrm{cm}^{2}\right)$ and IIHR $2890\left(7.36 \mathrm{~kg} / \mathrm{cm}^{2}\right)$. The firmness of the hybrids ranged from $5.02 \mathrm{~kg} / \mathrm{cm}^{2}$ to 8.78 $\mathrm{kg} / \mathrm{cm}^{2}$ with the hybrids IIHR $1816 \times$ IIHR 2890 and IIHR $2891 \times$ IIHR 2890 having least firm fruits with per se firmness of 5.02 $\mathrm{kg} / \mathrm{cm}^{2}$ and $5.85 \mathrm{~kg} / \mathrm{cm}^{2}$, respectively. The hybrids IIHR 2892 x IIHR 2852 and IIHR 977 x IIHR 2852 were more firm with a mean value of $8.78 \mathrm{~kg} / \mathrm{cm} 2$ and $7.46 \mathrm{~kg} / \mathrm{cm} 2$, respectively. Fruits with more number of locules found to be having more juice content in them, whereas fruits with lesser number of locules are said to be physically firmer. IIHR2891 (2.44) had minimum number of locules per fruits and hence better firmness, while IIHR 2853 (6.33) showed the maximum number of locules per fruit and hence more juice content in it. Lower number of locules per fruit was noticed in the hybrids IIHR 2891 x IIHR 2852 (3) and IIHR 977 x IIHR 2852 (3.11). Higher number of locules per plant was registered in the hybrids IIHR $1816 \mathrm{x}$ IIHR 2853 (6.28) and in IIHR $2850 \times$ IIHR 2853 (5.89). Arka Rakshak was found to have firmer fruits $\left(8.47 \mathrm{~kg} / \mathrm{cm}^{2}\right)$ than any of the other hybrids under study and the variations obtained for fruit firmness and number of locules is in accordance with the findings of Truong et al., 2015. Pericarp thickness of the fruit also contributes to the shipping and keeping quality of fruit by providing thick physical barrier against external stresses. Pericarp thickness of parents ranged from $5.55 \mathrm{~mm}$ (IIHR 2890) to $9.12 \mathrm{~mm}$ (IIHR 977) similarly, hybrids too displayed wide range of variation from $5.11 \mathrm{~mm}$ (IIHR $2892 \times$ IIHR 2853 ) to $9.22 \mathrm{~mm}$ (IIHR $2848 \times$ IIHR 2852) and these results were similar to the findings of Hazarika and Phookan (2005) and Renuka et al., 2014.

High total soluble solids (TSS) and low acidity are the major factors well thought-out for manufacture of processed products. One per cent increase in TSS content of fruits result in $20 \%$ increase in recovery of processed product (Berry et al., 1988 and Shivanand, 2008). Among the parents, IIHR 2890 showed the highest value for TSS

$\left(5.17^{\circ} \mathrm{B}\right)$ followed by IIHR $2848\left(4.85^{\circ} \mathrm{B}\right)$, IIHR 1816 (4.82 B), IIHR 2891 (4.71 B), IIHR 2852 (4.55 B) and IIHR 2853 (3.83 ${ }^{\circ}$ B). Check hybrid Abhinava had highest TSS of $5.03 \mathrm{~B}$, followed by IIHR 2850 x IIHR 2852 $\left(4.84{ }^{\circ} \mathrm{B}\right)$ and IIHR $2848 \times$ IIHR 2890 (4.72 B) in contrast to IIHR 2892 x IIHR 2853 $(3.90 \mathrm{~B})$ and in IIHR 2892 x IIHR 2852 $(3.94 \mathrm{~B})$ and this is in consonance with the experiments conducted by Suchindra et al., (2012) and Cheema et al., (2013). High ascorbic acid (Vitamin C) content was found in IIHR $1816(20.06 \mathrm{mg} / 100 \mathrm{~g})$, followed by IIHR $2848(18.46 \mathrm{mg} / 100 \mathrm{~g})$ and IIHR 2892 $(12.30 \mathrm{mg} / 100 \mathrm{~g})$. Among hybrids, low vitamin $\mathrm{C}$ content was observed in Abhinava (7.81mg), IIHR $2850 \quad x \quad$ IIHR 2852 $(8.06 \mathrm{mg} / 100 \mathrm{~g})$ and IIHR $2891 \mathrm{x}$ IIHR 2852 $(9.4 \mathrm{mg} / 100 \mathrm{~g})$, whereas highest vitamin $\mathrm{C}$ is recorded in IIHR $977 \mathrm{x}$ IIHR 2853 $(18.21 \mathrm{mg} / 100 \mathrm{~g})$ and IIHR $1816 \mathrm{x}$ IIHR 2890 $(17.51 \mathrm{mg} / 100 \mathrm{~g})$. Similar variation for TSS has been recorded by Renuka et al., 2014.

With growing health concerns round the globe, tomato provides an option in the form of dietary antioxidants, carotenoids and lycopene that are known to avoid many types of cancer. Additionally, lycopene also provides attractive red colour to the fruit and hence its content in the fruit is a matter of concern. 
Table.1 Per se performance of tomato parental lines for quality and yield traits

\begin{tabular}{|c|c|c|c|c|c|c|c|c|c|c|c|c|c|c|c|c|}
\hline Hybrid & $\begin{array}{l}\text { Days to } \\
\mathbf{5 0 \%} \\
\text { flowering }\end{array}$ & $\begin{array}{l}\text { Days to } \\
\text { first fruit } \\
\text { maturity }\end{array}$ & $\begin{array}{l}\text { Plant } \\
\text { height } \\
\text { (cm) }\end{array}$ & $\begin{array}{l}\text { Number } \\
\text { of } \\
\text { branches }\end{array}$ & $\begin{array}{l}\text { Fruit } \\
\text { firmness } \\
(\mathrm{kg} / \mathrm{cm} 2)\end{array}$ & $\begin{array}{l}\text { Number } \\
\text { of } \\
\text { locules }\end{array}$ & $\begin{array}{l}\text { TSS } \\
\text { (B) }\end{array}$ & $\begin{array}{l}\text { Pericarp } \\
\text { thickness } \\
(\mathrm{mm})\end{array}$ & $\begin{array}{l}\text { Vitamin C } \\
(\mathrm{mg} / \mathbf{1 0 0 g})\end{array}$ & $\begin{array}{l}\text { Total } \\
\text { carotenoids } \\
(\mathrm{mg} / 100 \mathrm{~g})\end{array}$ & $\begin{array}{l}\begin{array}{l}\text { Lycopene } \\
\text { (mg }\end{array} \\
\text { /100g) }\end{array}$ & $\begin{array}{l}\text { Fruits } \\
\text { per } \\
\text { cluster }\end{array}$ & $\begin{array}{l}\text { Fruit } \\
\text { length } \\
\text { (cm) }\end{array}$ & $\begin{array}{l}\text { Fruit } \\
\text { breadth } \\
(\mathrm{cm})\end{array}$ & $\begin{array}{l}\text { Average } \\
\text { fruit weight }\end{array}$ & $\begin{array}{l}\text { Yield/ } \\
\text { plant (kg) }\end{array}$ \\
\hline IIHR977 & 29 & 56.33 & 71.13 & 5.66 & 6.93 & 2.66 & 4.21 & 9.12 & 9.18 & 13.41 & 7.92 & 2.73 & 7.11 & 4.96 & 126.32 & 1.68 \\
\hline IIHR1816 & 28.33 & 59.33 & 63.42 & 5.57 & 6.47 & 4 & 4.82 & 8.39 & 20.06 & 6.61 & 3.68 & 3.13 & 6.16 & 6.51 & 136.9 & 2.69 \\
\hline IIHR2848 & 28.33 & 64.33 & 73.33 & 6.61 & 6.67 & 3.33 & 4.85 & 8.77 & 18.46 & 7.74 & 4.46 & 2.47 & 6.66 & 7.27 & 197.62 & 1.98 \\
\hline IIHR2850 & 31.67 & 62.67 & 73.24 & 5.8 & 8.14 & 3.89 & 4.52 & 7.87 & 14 & 5.34 & 2.92 & 2.07 & 6.33 & 7.42 & 177.75 & 2.17 \\
\hline IIHR2891 & 31.33 & 59.33 & 82.93 & 6.27 & 6.93 & 2.44 & 4.71 & 7.44 & 6.73 & 8.95 & 5.05 & 3.27 & 5.86 & 4.97 & 75.09 & 2.08 \\
\hline IIHR2892 & 28 & 62 & 74.9 & 5.8 & 6.89 & 3.89 & 4.18 & 6.55 & 12.3 & 11.3 & 6.18 & 2.73 & 5.24 & 5.38 & 120.37 & 2.86 \\
\hline IIHR2852 & 28.33 & 59.33 & 79.08 & 5.6 & 7.42 & 2.89 & 4.25 & 7.33 & 9.5 & 11.94 & 7.26 & 3.2 & 6.65 & 4.71 & 91.41 & 3.19 \\
\hline IIHR2853 & 29.67 & 57.67 & 89.54 & 5.33 & 8.37 & 6.33 & 4.05 & 6.61 & 9.4 & 13.09 & 7.51 & 2.53 & 6.38 & 7.4 & 144.82 & 3.31 \\
\hline IIHR2590 & 29.33 & 56.33 & 70.17 & 6.87 & 7.36 & 5.55 & 4.29 & 5.55 & 8.43 & 16.78 & 9.61 & 2.6 & 4.63 & 5.26 & 69.05 & 2.52 \\
\hline
\end{tabular}


Table.2 Per se performance of tomato hybrids and checks for quality and yield traits

\begin{tabular}{|c|c|c|c|c|c|c|c|c|c|c|c|c|c|c|c|c|}
\hline Hybrid & $\begin{array}{l}\text { Days to } \\
\mathbf{5 0 \%} \\
\text { flowering }\end{array}$ & $\begin{array}{l}\text { Days to first } \\
\text { fruit } \\
\text { maturity }\end{array}$ & $\begin{array}{l}\text { Plant } \\
\text { height } \\
(\mathrm{cm})\end{array}$ & $\begin{array}{l}\text { Number } \\
\text { of } \\
\text { branches }\end{array}$ & $\begin{array}{l}\text { Fruit } \\
\text { firmness } \\
(\mathrm{kg} / \mathrm{Cm} 2)\end{array}$ & $\begin{array}{l}\text { Number } \\
\text { of } \\
\text { locules }\end{array}$ & $\begin{array}{l}\text { TSS } \\
\text { (B) }\end{array}$ & $\begin{array}{l}\text { Pericarp } \\
\text { thickness } \\
(\mathrm{mm})\end{array}$ & $\begin{array}{l}\text { Vitamin C } \\
(\mathbf{m g} / \mathbf{1 0 0 g})\end{array}$ & $\begin{array}{l}\text { Total } \\
\text { carotenoids } \\
(\mathbf{m g} / \mathbf{1 0 0 g})\end{array}$ & $\begin{array}{l}\text { Lycopene } \\
\text { (mg/100g) }\end{array}$ & $\begin{array}{l}\text { Fruits } \\
\text { per } \\
\text { cluster }\end{array}$ & $\begin{array}{l}\text { Fruit } \\
\text { length } \\
(\mathrm{cm})\end{array}$ & $\begin{array}{l}\text { Fruit } \\
\text { breadth } \\
\text { (cm) }\end{array}$ & $\begin{array}{l}\text { Average } \\
\text { fruit } \\
\text { weight }\end{array}$ & $\begin{array}{l}\text { Yield/ } \\
\text { plant }(\mathbf{k g})\end{array}$ \\
\hline $\begin{array}{l}\text { IIHR977 x } \\
\text { IIHR2852 }\end{array}$ & 27.67 & 59.33 & 84.17 & 6.43 & 7.46 & 3.11 & 4.25 & 7.03 & 13.92 & 20.62 & 12.75 & 3.15 & 6.39 & 5.43 & 100.67 & 2.73 \\
\hline $\begin{array}{l}\text { IIHR977 x } \\
\text { IIHR2853 }\end{array}$ & 31.33 & 57.67 & 90.58 & 6.67 & 6.63 & 3.77 & 4.05 & 6.22 & 18.21 & 13.5 & 8.04 & 3.33 & 5.75 & 5.36 & 109 & 3.88 \\
\hline $\begin{array}{l}\text { IIHR977 x } \\
\text { IIHR2890 }\end{array}$ & 29 & 56.33 & 76.17 & 7.2 & 6.92 & 4.11 & 4.29 & 7.11 & 11.75 & 8.45 & 4.69 & 3.27 & 5.48 & 5.72 & 80.3 & 3.23 \\
\hline $\begin{array}{l}\text { IIHR1816 x } \\
\text { IIHR2852 }\end{array}$ & 27.33 & 57.33 & 84.58 & 6.2 & 6.49 & 4.11 & 4.12 & 7.6 & 10.18 & 18.52 & 11.8 & 2.47 & 6.04 & 5.31 & 120.37 & 3.19 \\
\hline $\begin{array}{l}\text { IIHR1816 x } \\
\text { IIHR2853 }\end{array}$ & 27.33 & 57.33 & 79.75 & 5.33 & 6.64 & 6.28 & 4.06 & 7.05 & 9.95 & 20.96 & 13.3 & 2.87 & 6.08 & 6.87 & 140.19 & 3.66 \\
\hline $\begin{array}{l}\text { IIHR1816 x } \\
\text { IIHR2890 }\end{array}$ & 27.67 & 58.67 & 73.67 & 6.07 & 5.02 & 4.5 & 4.27 & 6.32 & 17.51 & 12.22 & 7.55 & 2.47 & 5.19 & 5.85 & 155.95 & 3.29 \\
\hline $\begin{array}{l}\text { IIHR2848 x } \\
\text { IIHR2852 }\end{array}$ & 28.33 & 59.67 & 84.83 & 6 & 8.14 & 4.33 & 4.65 & 9.22 & 11.06 & 9.17 & 5.51 & 2.33 & 6.08 & 6.82 & 128.55 & 2.71 \\
\hline $\begin{array}{l}\text { IIHR2848 x } \\
\text { IIHR2853 }\end{array}$ & 28.67 & 62.33 & 91.08 & 5.2 & 7.01 & 4.78 & 4.22 & 8.44 & 10.28 & 13.8 & 8.59 & 2.13 & 7.5 & 6.85 & 194.44 & 3.67 \\
\hline $\begin{array}{l}\text { IIHR2848 x } \\
\text { IIHR2890 }\end{array}$ & 28.67 & 62.33 & 84.58 & 6.77 & 6.73 & 5.22 & 4.72 & 8.44 & 10.18 & 8.9 & 5.11 & 2.55 & 5.75 & 6.67 & 104.37 & 2.96 \\
\hline $\begin{array}{l}\text { IIHR2850 x } \\
\text { IIHR2852 }\end{array}$ & 27.67 & 61.33 & 88.58 & 5.93 & 6.51 & 4.94 & 4.84 & 7.77 & 8.06 & 13.04 & 8.08 & 2.6 & 6.34 & 6.51 & 140.21 & 4.07 \\
\hline $\begin{array}{l}\text { IIHR2850x } \\
\text { IIHR2853 }\end{array}$ & 28.33 & 61.67 & 80.58 & 5.83 & 7.11 & 5.89 & 4.4 & 7.44 & 10.98 & 12.54 & 7.63 & 2.2 & 6.42 & 7.55 & 132.24 & 3.67 \\
\hline $\begin{array}{l}\text { IIHR2850 x } \\
\text { IIHR2890 }\end{array}$ & 29 & 57.33 & 76.5 & 5 & 7.27 & 4.22 & 4.62 & 7 & 9.74 & 6.34 & 3.75 & 2.67 & 5.21 & 5.85 & 76.77 & 3.25 \\
\hline $\begin{array}{l}\text { IIHR2891 x } \\
\text { IIHR2852 }\end{array}$ & 26.33 & 57.67 & 86.08 & 5.92 & 6.95 & 3 & 4.47 & 6.22 & 9.4 & 9.8 & 5.85 & 3.08 & 6.64 & 5.43 & 88.89 & 3.26 \\
\hline $\begin{array}{l}\text { IIHR2891 x } \\
\text { IIHR2853 }\end{array}$ & 27.33 & 56.67 & 87.33 & 6.53 & 7.11 & 4 & 4.71 & 6.44 & 13.25 & 21.19 & 13.49 & 2.47 & 6.28 & 5.75 & 96.01 & 3.02 \\
\hline $\begin{array}{l}\text { IIHR2891 x } \\
\text { IIHR2890 }\end{array}$ & 28.67 & 58 & 80.75 & 5.2 & 5.85 & 5.33 & 4.53 & 5.99 & 10.15 & 13.54 & 8.31 & 2.8 & 5.15 & 5.84 & 91.41 & 3 \\
\hline $\begin{array}{l}\text { IIHR2892 x } \\
\text { IIHR2852 }\end{array}$ & 27.67 & 58 & 86.33 & 5.87 & 8.78 & 5.33 & 3.94 & 6.61 & 12.64 & 24.17 & 15.11 & 2.8 & 5.62 & 6.67 & 117.06 & 3.19 \\
\hline $\begin{array}{l}\text { IIHR2892 x } \\
\text { IIHR2853 }\end{array}$ & 30.33 & 57.67 & 80.33 & 5.8 & 7.09 & 4.33 & 3.9 & 5.11 & 12.85 & 11.66 & 7.01 & 2.6 & 5.37 & 6.39 & 116.67 & 3.22 \\
\hline $\begin{array}{l}\text { IIHR2892 x } \\
\text { IIHR2890 }\end{array}$ & 28.67 & 58 & 76.17 & 6.1 & 5.97 & 4.33 & 4.45 & 5.77 & 13.54 & 9.48 & 5.41 & 2.87 & 4.84 & 5.69 & 104.34 & 2.88 \\
\hline $\begin{array}{l}\text { Arka } \\
\text { Rakshak }\end{array}$ & 31 & 62.33 & 83.75 & 5.67 & 8.47 & 3.22 & 4.39 & 7.83 & 12 & 12.96 & 8.02 & 3.47 & 6.54 & 5.25 & 103.7 & 4.55 \\
\hline Abhinava & 29.67 & 60.33 & 89.42 & 5.43 & 6.72 & 2.67 & 5.03 & 6.11 & 7.81 & 20.43 & 12.9 & 3.47 & 6.37 & 5.09 & 85.85 & 3.47 \\
\hline
\end{tabular}


Table.3 Best performing hybrids in relation to commercial checks

\begin{tabular}{|l|l|l|l|l|l|l|}
\hline \multicolumn{1}{|c|}{ Hybrids } & Yield/plant & $\begin{array}{c}\text { Average fruit } \\
\text { weight }\end{array}$ & \multicolumn{1}{|c|}{ Vitamin C } & Carotenoids & Lycopene & \multicolumn{1}{c|}{$\begin{array}{c}\text { Pericarp } \\
\text { thickness }\end{array}$} \\
\hline IIHR1816 x IIHR2852 & 3.19 & 120.37 & 10.18 & 18.52 & 11.8 & 7.6 \\
\hline IIHR1816 x IIHR2853 & 3.66 & 140.19 & 9.95 & 20.96 & 13.3 & 7.05 \\
\hline IIHR1816 x IIHR2890 & 3.29 & 155.95 & 17.51 & 12.22 & 7.55 & 6.32 \\
\hline IIHR2850 x IIHR2852 & 4.07 & 140.21 & 8.06 & 13.04 & 8.08 & 7.77 \\
\hline IIHR2891 x IIHR2853 & 3.02 & 96.01 & 13.25 & 21.19 & 13.49 & 6.44 \\
\hline IIHR2892 x IIHR2852 & 3.19 & 117.06 & 12.64 & 24.17 & 15.11 & 6.61 \\
\hline IIHR2892 x IIHR2890 & 2.88 & 104.34 & 13.54 & 9.48 & 5.41 & 5.77 \\
\hline ArkaRakshak & 4.55 & 103.70 & 12.00 & 12.96 & 8.02 & 7.83 \\
\hline Abhinava & 3.47 & 85.85 & 7.81 & 20.43 & 12.90 & 6.11 \\
\hline
\end{tabular}

Total carotenoids content oscillated from $11.94 \mathrm{mg} / 100 \mathrm{~g}$ (IIHR 2852) to $16.78 \mathrm{mg} / 100 \mathrm{~g}$ (IIHR 2890) among parents. The $F_{1}$ 's showed wider range of variation from $6.34 \mathrm{mg} / 100 \mathrm{~g}$ (IIHR $2850 \times$ IIHR 2890) to $24.17 \mathrm{mg} / 100 \mathrm{~g}$ (IIHR 2892 x IIHR 2852) with checks, Arka Rakshak and Abhinava recording $12.96 \mathrm{mg} / 100 \mathrm{~g}$ and $20.43 \mathrm{mg} / 100 \mathrm{~g}$, respectively. A greater range of variation was observed among the parents $(2.92 \mathrm{mg}$ to $9.61 \mathrm{mg} / 100 \mathrm{~g}$ ) for lycopene content similar to that of the hybrids, ranging between $3.75 \mathrm{mg} / 100 \mathrm{~g}$ (IIHR $2850 \times$ IIHR 2890) and $15.11 \mathrm{mg} / 100 \mathrm{~g}$ (IIHR $2892 \times$ x IIHR 2852), however Arka Rakshak and Abhinava recorded $12.9 \mathrm{mg} / 100 \mathrm{~g}$ and $8.02 \mathrm{mg} / 100 \mathrm{~g}$, respectively. Very good variation among hybrids for quality characters like ascorbic acid, lycopene and TSS was also observed by Lekshmi and Celine (2015).

\section{Yield attributing traits}

Number of fruits, fruit size and average fruit weight are the entities that directly contribute to the yield per plant and thereby to total yield per unit area. A wide range of variation was observed for fruits per cluster in hybrids with IIHR 2848 x IIHR 2853 (2.13) and IIHR 2850 $\mathrm{x}$ IIHR 2853 (2.22) having less number of fruits per cluster and IIHR 977 x IIHR 2853 (3.33) and IIHR 977 x IIHR 2890 (3.27) having more number of fruits per cluster. Parental line, IIHR 2853 (3.33) had more number of fruits per cluster followed by IIHR 2890 (3.27), IIHR 2891 (3.27) and IIHR 2852 (3.15). Fruit length varied from $4.63 \mathrm{~cm}$ (IIHR 2890) to $7.11 \mathrm{~cm}$ (IIHR 977), whereas the mean value of hybrids was in range of $5.15 \mathrm{~cm}$ (IIHR $2891 \times$ IIHR 2890) to $7.50 \mathrm{~cm}$ (IIHR $2848 \times$ IIHR 2853). The fruit breadth of the parental lines varied from $4.71 \mathrm{~cm}$ (IIHR 2852 ) to $7.42 \mathrm{~cm}$ (IIHR 2850) with the hybrids ranging from $5.31 \mathrm{~cm}$ (IIHR $1816 \mathrm{x}$ IIHR 2852) to $7.55 \mathrm{~cm}$ (IIHR $2850 \times$ IIHR 2853 ). The magnitude of variation among the parents with respect to fruit weight varied from $69.05 \mathrm{~g}$ in IIHR 2890 to $197.62 \mathrm{~g}$ in IIHR 2848. IIHR $1816 \times$ IIHR 2890 recorded the highest fruit weight of $155.95 \mathrm{~g}$, while IIHR 2850 x IIHR 2890 displayed minimum fruit weight of $76.77 \mathrm{~g}$. Among the parents, a range of variation from $1.68 \mathrm{~kg}$ (IIHR 977) to IIHR $2853(3.31 \mathrm{~kg})$ while, the highest yield of 4.07 $\mathrm{kg} /$ plant was recorded by IIHR $2850 \mathrm{x}$ IIHR 2852, which is comparatively higher than that of Abhinava $(3.47 \mathrm{~kg}$ ) but low yielder than that of Arka Rakshak (4.55kg). Other best yielding hybrids include IIHR 977 x IIHR $2853(3.88 \mathrm{~kg})$, IIHR $2848 \times$ IIHR 2853 and 
IIHR 2850 x IIHR 2853 (3.67kg). Results obtained by Ali et al., (2012), Shresta and Sah (2014), Lekshmi and Celine (2015), for fruit length, fruit diameter, average fruit weight and yield per plant also shown similar pattern as of in this experiment. None of the hybrids was found to be superior for all the characters under the study, whereas hybrids like IIHR1816 x IIHR2852, IIHR1816 x IIHR2853, IIHR1816 x IIHR2890, IIHR2850 $\mathrm{x}$ IIHR2852, IIHR2891 x IIHR2853, IIHR2892 x IIHR2852 and IIHR2892 x IIHR2890 were found to be embedded with most of the quality and yield traits in them (Table 3), which can be used for cultivation under the conditions of Bengaluru after further necessary evaluations.

\section{References}

Ali, W., Jilani, M.S., Naeem, N., Waseem, K., Khan, J., Ahmad, M.J. and Ghazanfarullah. 2012. Evaluation of different hybrids of tomato under the climatic conditions of Peshawar. Sarhad J. Agric., 28(2): 207-212.

Anonymous. 2016. Indian horticulture database 2015, National horticulture board. Retrieved from www.nhb.gov.in.

Arun, J., Amit, V. and Thakur, M.C. 2004. Studies on genetic variability, correlation and path analysis for yield physio-chemical traits in tomato (Lycopersicon esculentum Mill.). Prog. Hort., 36(1): 51-58.

Berry, S.Z. and Rafique-Ud-Din, M. 1988. Effect of high temperature on fruit set in tomato cultivars and selected germplasm. Hort. Sci., 23: 606-608.

Cheema, D.S., Singh, N. and Jindal, S.K. 2013. Evaluation of indeterminate tomato hybrids for fruit, yield and quality traits under net house and open field conditions. Veg. Sci., 40(1): 45-49.
Hazarika, T.K. and Phookan, D.B. 2005. Performance of tomato cultivars for polyhouse cultivation during spring summer in Assam. Indian J. Hort. 62(3): 268-271.

Lekshmi, S.L. and Celine, V.A. 2015. Evaluation of tomato hybrids for fruit, yield and quality traits under polyhouse conditions. International Journal of Applied and Pure Science and Agriculture, 1(7): 58-64.

Leonardi, C., Ambrosino, P., Esposito, F., and Fogliano, V. 2000. Antioxidative activity and carotenoid and tomatine contents in different typologies of fresh consumption tomatoes. $J$. Agric. Food Chem. 48: 4723- 4727.

Rao, A. V. and Rao, L. G. 2007. Carotenoids and human health. Pharmacol. Res. 55: 207-216.

Renuka, D.M., Sadashiva, A.T., Kavita, B.T., Vijendrakumar, R.C. and Hanumanthiah, M.R. 2014. Evaluation of cherry tomato lines (Solanum lycopersicum Var. cerasiforme) for growth, yield and quality traits. Plant Archives. 14(1): 151-154.

Rick, C.M. 1969. Origin of cultivated tomato (Lycopersicon esculentum Mill.). Current status of problem. Abstract, XI International Congress, $\mathrm{p}-180$.

Shivanand, V.H. 2008. Evaluation of tomato (Lycopersicon esculentum Mill.) hybrids under Eastern dry zone of Karnataka, M.Sc. Thesis, UAS, GKVK, Bangalore.

Shrestha, S.L. and Sah, R.L. 2014. Evaluation of Tomato Cultivars for Central Tarai of Nepal. Nepal Journal of Science and Technology. 15(2): 11-16.

Suchindra, R., Sankaranarayanan, R. and Nainar, P. 2012. Studies on evaluation of tomato (Solanum lycopersicum L.) hybrids under four different growing environments for quality characters. Plant Archives 12(1): 257-258.

Truong, H.T.H., Phan, T.T. and Le, K.T. 2015. Evaluation on Agronomical Characteristics of $\mathrm{F}_{1}$ Hybrid Tomato Lines in Spring-Summer Season 2015 in Thua Thien Hue. J. Agri. Sci. Technol. A and B \& Hue University J. Sci., 5: 501-507.

\section{How to cite this article:}

Bharathkumar, M.V., A.T. Sadashiva and Pradeep Kumar Jatav. 2017. Performance of a Set of Tomato Parental Lines and their Hybrids for Quality and Yield under Conditions of Bengaluru, India. Int.J.Curr.Microbiol.App.Sci. 6(5): 786-793.

doi: https://doi.org/10.20546/ijcmas.2017.605.089 